\title{
Factor Affecting Hand- Loom Workers' Performance: A Case Study on Shirajganj District in Bangladesh
}

\author{
Abid Aziz, Md. Monowar Uddin Talukdar, Mitaly Rani Sarkar, Mohitul Ameen Ahmed Mustafi
}

\begin{abstract}
The loom sector in Bangladesh has a lot of potential in terms of contributing to large-scale cloth production. It is one of the more beneficial aspects of small and medium businesses. Many workers were employed in this location, and some were either satisfied or dissatisfied with their performance. The goal of this study has been designed to focus on the influential elements that have influenced the performance of handloom workers in Bangladesh. Both primary and secondary data sources were employed in this investigation. A structured questionnaire with five-point scales was used to collect data, with 1 indicating complete disagreement and 5 indicating complete agreement. Both descriptive and inferential statistics were employed to analyze the data. Inferential statistics were used to discover the elements that affect hand-loom workers' performance in Bangladesh. Descriptive statistics were used to explain the characteristics of handloom workers in Bangladesh. The data was collected from active hand-loom workers using a suitable sampling strategy. Using the structural equation approach, we discovered three influential characteristics that are key connectors with the performance of hand-loom workers: factory people's political skill, job happiness, and motivation. People work in their factories to be fulfilled, motivated, and to have a heart-to-heart relationship with their co-workers, which the factory owner must be very attentive about.
\end{abstract}

Keywords: Bangladesh, Hand-Loom Workers Performance, Job Satisfaction, Compensation, Motivation, Factory Commitment, Factory People Political Skill, Shirajganj (Rural Area).

\subsection{Introduction}

In Bangladesh, the handloom industry was one of the traditional profit-generating sectors. The handloom industry is now on the verge of extinction due to a variety of issues. The Bangladesh Bureau of Statistics (BBS) conducted the 3rd Handloom Census 2018 from 10 to 14 May 2018 to determine the current number of handloom workers and the general state of the sector, which revealed a disturbing picture. Workers in the handloom sector are also reducing at a quick rate due to the rapid decline of the business. Workers' performance must be measured as an intrinsic element of the handloom industry's demise in order to make these drastic changes. It answers the unemployment difficulties of this manpower-based country due to its labor-intensive nature, as evidenced by the direct and indirect engagement of more than 301757 (1.5 million in 2003) workers in this occupation (Parvin \& Haque, 2017) According to a BBS data from 2018, the direct involvement of hand loom weavers in Sirajganj district is more than.06 million. Different criteria are examined to determine which ones have the greatest impact on worker performance. The handloom industry was a key source of income in Bangladesh's Sirajganj district. It is also one of the largest and most important cottage industries (Islam M., Costbenefit analysis of handloom weaving industry in kumarkhali upazila of Kushtia District, Bangladesh, 2013), as well as the second largest source of rural employment after agriculture (Islam M., Cost-benefit analysis of handloom weaving industry in kumarkhali upazila of Kushtia District, Bangladesh, 2013). (Liton , Islam, \& Saha, 2016). During the three censuses in 1990, 2003, and 2018, the total number of handloom units in Bangladesh decreased. In 1990, there were 212421 handloom units, which had declined by 13.61 percent to 183512 in 2003. However, in 2018, the overall number of handloom units was 116006 , down 36.79 percent from 2003 and 45.39 percent from 1990 censuses (PRELIMINARY REPORT (HANDLOOM CENSUS 2018), 2018). Handlooms are traditionally household units (Banarjee, Muzib, \& Sharmin, 2014), with 99.50 percent belonging to households and 0.50 percent as an industry or factory. However, in Sirajganj District, 9766 handloom units are working for production, with 9541 belonging to households and 225 with factory or industry, employing 44236 male and 16107 female workers. According to the BBS report 2018, Sirajganj District has 8.42 percent handloom units and ranks fifth in Bangladesh (PRELIMINARY REPORT (HANDLOOM CENSUS 2018), 2018). In Bangladesh, there are two categories of weavers: family workers and contracted workers (Liton M. R., 2020). It is known as the weaving industry's basis for supplying the majority of home fabric demand (Islam \& Hossain, An analysis of Present Scenario of Handloom Weaving Industry in Bangladesh, 2012). In Bangladesh, there are primarily six types of looms. In Bangladesh, these are pit loom, frame loom, Chittarangan loom, Banarasi or Jamdani loom, Komar or waist loom, and power loom (Islam \& Hossain, An Analysis of Present Scenario of Handloom Weaving Industry in Bangladesh, 2012), although pit loom and Japani loom may be found in Sirajganj district. However, handloom weaving activities in Bangladesh are dwindling, and many weaving facilities have closed owing to a variety of issues (Islam M. , Cost-benefit analysis of handloom weaving industry in kumarkhali upazila of Kushtia District, Bangladesh, 2013). Agriculture, on the other hand, is a seasonal industry that already has a surplus of workers. As a result, rural residents face hidden and seasonal unemployment. It is impossible to improve the country's economic progress without improving the economic situation of rural people (Raihan, 2010).

\subsection{Literature Review}

\subsection{Hand- loom workers performance}

Despite the ongoing development of firms and the continuing rise in market standards, attaining the 
maximum level of performance is becoming increasingly more difficult. This entails not only offering high-quality service and products, but also having a highly productive workforce. A strong company will always attract and retain talents (Vosloban, 2012).

As an outcome, employees will be more confident that their knowledge, skills, and behaviors play a significant role in attaining higher job performance that will have a positive impact on their overall job performance in the long run. As a function, managers and supervisors play an essential part in preserving and strengthening the behavioral aspects of employee belonging and affirmation in the workplace. Managers should consider enhancing a company's training culture to assist employees in acquiring new job-related knowledge, skills, and abilities that would allow them to be more proactive and adaptive when presented with various job execution-related challenges (Diamantidis \& Chatzoglou, 2019).

Managers should consider strengthening a regarding the training culture to assist employees in obtaining new jobrelated knowledge, skills, and abilities that will allow them to be more proactive and adaptive when confronted with various job execution-related challenges. Furthermore, the study's findings suggest a substantial negative connection between turnover intentions and work performance, suggesting that employees with such a lower probability of quitting perform better. Work-related indicators such as job satisfaction, turnover intentions, and job-specific self-efficacy are all shown to be closely related to human performance in organizations in the current study (Randhawa, 2007).

\subsection{Job satisfaction}

Job satisfaction has a great impact on the willingness to the work (Benrazavi \& Seyed Rahim 2013) as well as an increase in job performance. One of a company's numerous tasks is to satisfy its personnel in order to manage with an ever-changing and evolving environment, achieve success, and stay competitive. The business must meet the needs of its employees by providing ideal working conditions in order to increase efficiency, effectiveness, productivity, and job commitment. Job satisfaction is a critical factor in motivating and encouraging employees to achieve higher levels of performance (Abdul \& Maulabakhsh, 2014). Specifically, the findings show that job happiness has a strong beneficial connection with scientists' performance. So, for increasing the performance, care should be taken to enhance the level of satisfaction of employees. Autonomous and challenging jobs, performance-based pay, a pleasant working environment, and flexible working hours are just a few of the methods to make a job more exciting and satisfying (Randhawa, 2007).

Hypothesis 01: There is positive relationship between job satisfaction and hand-loom workers performance in Bangladesh

\subsection{Factory Commitment}

When it comes to making judgments on their workers, company managers and leaders often have to deal with insufficient information. Information on employees' commitment and engagement in their work is extremely useful for management in making effective decisions (Einolander \& Jarno, 2015). Other commitment forms, including such commitment to the occupation, the job, the workgroup, the union, and the work itself, have already been influenced by the conceptual and operational development of organizational commitment (Cohen, 2007).

Hypothesis 02: There is positive relationship between factory commitment and hand-loom workers performance in Bangladesh

\subsection{Compensation}

Employees are attracted to, engaged by, and motivated by compensation. In exchange for income, employees use their talents, expertise, and effort. Compensation refers to the total cost of labor, which includes wage and benefits (Patnaik \& Suar, 2019). If some industries and their efforts are more responsive to compensation rather than other motivational stimuli such as promotions or development, the influence of remuneration on performance could be even more crucial. In this sense, studying the compensation effect in a particular industry can help in gaining knowledge of how pay affects employee psychology and, eventually, organizational performance (Hong Soon Kim \& Jang SooCheong Shawn, 2020). The level of board cash compensation is influenced by the nature of the ownership, with stateowned firms paying less and family-owned firms paying more; furthermore, the level of board compensation is influenced by the wedge, even if, contrary to expectations, pay is lower in firms with higher wedge. (Barontini \& Bozzi, 2009). Although labor economists and organizational theorists have given the topic of wage disparity among managing team members considerable attention, little empirical study has been done to yet. (Lee, Lev, \& Heng Yeo, 2008). Even though there is no research on the influence of compensation system implementation on employee pay satisfaction, there is research on the impact of compensation system implementation on employee pay satisfaction. (Morgeson, Campion, \& Maertz, 2021).

Hypothesis 03: There is positive relationship between compensation and hand-loom workers performance in Bangladesh

\subsection{Motivational factor}

Many academics believe that high-tech solutions will never be able to completely replace humans in the workplace. The science of motivation remains the key to answers in motivating people to cope with a variety of organizational and work changes at the beginning of the fourth industrial revolution. (Reeve, 2018). In the case of the handloom industry, a variety of variables drive the handloom owner to participate in the handloom industry. Some are motivated by a great desire to support their families, while others are motivated by the goal to make them self-sufficient. Each of the study's handloom owners has their own motivation for starting the business. Some people start businesses because they are unemployed, while others do their jobs in the usual way (Dutta, 2020).

Hypothesis 04: There is positive relationship between motivation and hand-loom workers performance in Bangladesh

\subsection{Factory people political skill}

This study develops and tests a framework in which managerial political skill is associated with internal, supplier, and customer supply chain integration through two mediating mechanisms: facilitating a supply chain orientation and mitigating self-serving politics, based on social exchange theory, social capital theory, and 
perspectives of political influence in organizations. (Bentley, Robinson, \& Zanhour, 2021). There has been very little systematic research into what plant managers do on a daily basis that accounts for their success in accomplishing organizational goals. Here are several examples: In manufacturing plants, there are a variety of behavioural challenges that need to be addressed. Plant managers, in their capacity as middle managers, Politics in the workplace and political savvy (Smith, Plowman, Duchon, \& Quinn). Political skill is a type of social skill that differs from other social skills in that it is defined as an interpersonal style that blends social awareness with the capacity to speak effectively (Ferris et al., 2000). Political skill has received more attention as an indicator of work performance and attitudes in the field of social effectiveness theories. The current study's findings suggest that political skill is linked to work satisfaction and turnover intentions (Banister \& Meriac, 2015).

Hypothesis 05: There is positive relationship between factory people political skill and hand-loom workers performance in Bangladesh

\subsection{Conceptual Framework}

The goal of this research is to see how job happiness, pay, motivation, factory dedication, and factory people's political skills affect hand-loom workers. Bangladesh's performance. For each of the hypotheses in the next section, we looked at the conceptual model in figure 1 .

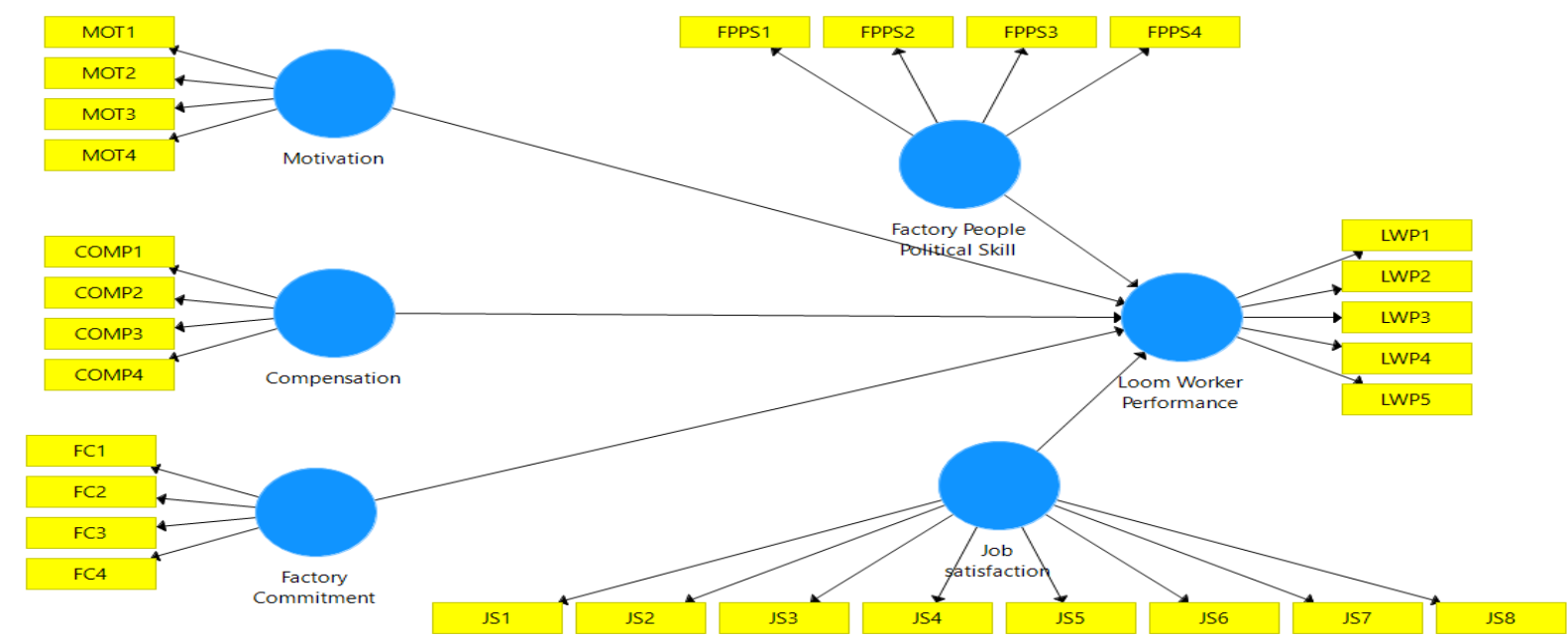

Figure 01: The conceptual framework of the effect of job satisfaction, compensation, motivation, factory commitment, factory people political skill on hand-loom workers Performance at Shirajganj in Bangladesh.

\subsection{Objectives of the study}

$>$ To identify the significant factors concerning the performance of hand-loom workers at Shirajganj district in Bangladesh.

\subsection{Research Methodology}

We used both primary and secondary data. The core data was gathered by interviewing 140 hand-loom workers in Shirajganj District. The data was collected using a standardized questionnaire with 29 questions. Data was collected by a group of students from Khwaja Yunus Ali University's BBA program, who were given proper training and careful supervision. To identify the convenience sample respondents who were gathered using the convenience sampling method. Incomplete, biased, and improperly responded data were deleted after a thorough examination. To compile the data and conduct descriptive analyses, we used the SPSS 26.0 software. SmartPLS-3 was utilized to discover the elements that influenced hand-loom workers' performance in Shirajganj, Bangladesh. The reliability of 29 items in the questionnaire was assessed using SPSS software, and the acceptability limit was determined using the Cronbach's Alpha Coefficient, as recommended by Nunnally (1967 and 1978). A systematic questionnaire was utilized to determine parameters influencing the performance of hand-loom workers in Bangladeshi loom manufacturers. The Likert scale was employed, with a 5-point scale ranging from 1 to 5 , with 1 indicating strong disagreement and 5 indicating strong agreement. To discover the main factors affecting the performance of hand-loom workers in Bangladesh, inferential statistical approaches such as Factor Analysis (EFA) and Structural Equation Modeling (SEM) were utilized. The data was analyzed in three stages: data screening, measurement model validation, and structural model evaluation (Hair, Ringle \& Sarstedt 2011). In the data screening procedure, IBM SPSS Statistics version 26 was employed. There were no missing data when the data was screened. For the evaluation of measurement and structural models, partial least squares structural equation modeling (PLS) and SmartPLS 3.0 were used as analytical tools. Structural Equation Modeling (SEM) may evaluate latent variables in a measurement model and test various associations between latent variables in a structural model at the same time (Hair, Sarstedt, Ringle \& Mena 2012b). PLS (Partial Least Squares) is an appropriate method for a study that seeks to apply and forecast structural correlations rather than confirm them (Hair, Ringle \& Sarstedt 2011).

\subsection{Normality of the data}


According to Tabachnick and Fidell (2001), skewness and kurtosis statistics with values ranging from -4 to +4 are considered acceptable. Table 1 shows that all of the Table 01: Normality of the data data were within the allowed range, indicating that they were distributed normally.

\begin{tabular}{|c|c|c|c|c|c|c|c|}
\hline \multicolumn{8}{|c|}{ Descriptive Statistics } \\
\hline & \multirow{2}{*}{\begin{tabular}{|l|}
$\mathrm{N}$ \\
Statistic
\end{tabular}} & \multirow{2}{*}{\begin{tabular}{|l|} 
Mean \\
Statistic
\end{tabular}} & \multirow{2}{*}{\begin{tabular}{|l} 
Std. Deviation \\
Statistic
\end{tabular}} & \multicolumn{2}{|l|}{ Skewness } & \multicolumn{2}{|l|}{ Kurtosis } \\
\hline & & & & Statistic & Std. Error & Statistic & Std. Error \\
\hline MOT1 & 140 & 2.7357 & .87828 & .416 & .205 & -.438 & .407 \\
\hline MOT2 & 140 & 2.8143 & .93367 & .326 & .205 & -.498 & .407 \\
\hline MOT3 & 140 & 2.7714 & .92404 & .417 & .205 & -.123 & .407 \\
\hline MOT4 & 140 & 3.0286 & .90516 & -.057 & .205 & -.715 & .407 \\
\hline COMP1 & 140 & 2.6571 & .98017 & .132 & .205 & -.973 & .407 \\
\hline COMP2 & 140 & 3.2714 & .93565 & -.569 & .205 & -.686 & .407 \\
\hline COMP3 & 140 & 2.5857 & .98905 & .233 & .205 & -.561 & .407 \\
\hline COMP4 & 140 & 2.6786 & 1.01972 & .227 & .205 & -1.049 & .407 \\
\hline FC1 & 140 & 2.4357 & .97605 & 1.054 & .205 & .485 & .407 \\
\hline FC2 & 140 & 2.3429 & .98749 & .811 & .205 & .187 & .407 \\
\hline FC3 & 140 & 2.2071 & .83534 & 1.020 & .205 & 1.350 & .407 \\
\hline FC4 & 140 & 2.2786 & .89818 & .869 & .205 & .510 & .407 \\
\hline FPPS1 & 140 & 4.0571 & .69708 & -.595 & .205 & .783 & .407 \\
\hline FPPS2 & 140 & 4.0357 & .73368 & -.943 & .205 & 2.164 & .407 \\
\hline FPPS3 & 140 & 4.0429 & .69811 & -.702 & .205 & 1.895 & .407 \\
\hline FPPS4 & 140 & 4.0357 & .68289 & -.595 & .205 & 1.777 & .407 \\
\hline LWP1 & 140 & 3.9214 & .62407 & -1.206 & .205 & 3.093 & .407 \\
\hline LWP2 & 140 & 3.8643 & .64830 & -.827 & .205 & 1.601 & .407 \\
\hline LWP3 & 140 & 4.0500 & .63840 & -1.052 & .205 & 3.069 & .407 \\
\hline LWP4 & 140 & 3.8500 & .69866 & -.942 & .205 & 2.211 & .407 \\
\hline LWP5 & 140 & 3.6643 & .75494 & -.474 & .205 & .592 & .407 \\
\hline JS1 & 140 & 3.7429 & .69294 & -.924 & .205 & 1.807 & .407 \\
\hline JS2 & 140 & 3.8857 & .71051 & -.931 & .205 & 2.168 & .407 \\
\hline JS3 & 140 & 3.8500 & .74838 & -.792 & .205 & 1.415 & .407 \\
\hline JS4 & 140 & 3.7071 & .77270 & -.958 & .205 & 1.576 & .407 \\
\hline JS5 & 140 & 3.7071 & .71466 & -.822 & .205 & 1.348 & .407 \\
\hline JS6 & 140 & 3.8786 & .79085 & -.931 & .205 & 1.363 & .407 \\
\hline JS7 & 140 & 3.7714 & .73301 & -.725 & .205 & 1.265 & .407 \\
\hline JS8 & 140 & 3.2143 & .90391 & -.201 & .205 & -.254 & .407 \\
\hline
\end{tabular}

\subsection{Multivariate Normality}

To see if there were any (multivariate) influential outliers, the authors used a cook's distance analysis (figure-2). There was no case in this study where a cook's distance

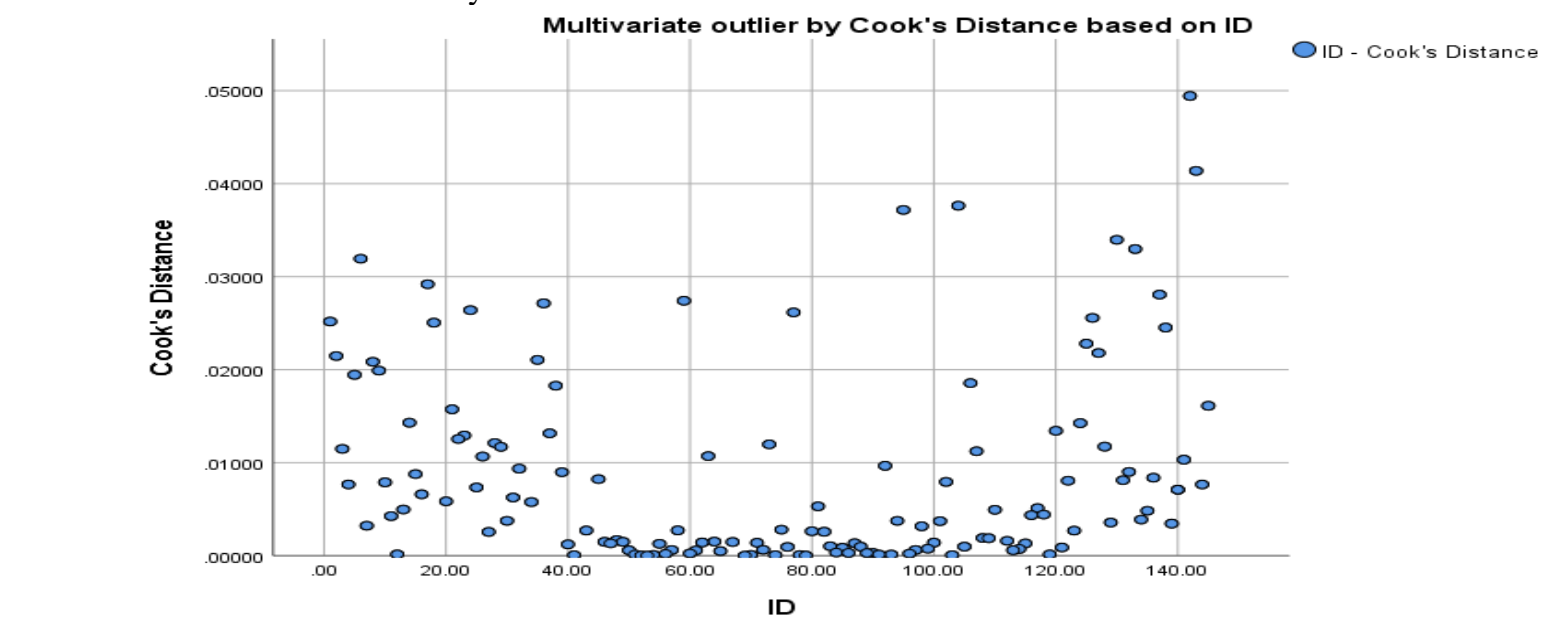

was more than 1 . The majority of the instances had a value of less than 0.05 . As a result, this result suggests that all of the pieces are dispersed normally.

Picture 01: Multivariate normality of the data 


\subsection{Demographic information of the workers who were worked in hand-loom factory at Sirajganj district in} Bangladesh

Table 02: Personal Information of the hand-loom workers of Sirajganj district in Bangladesh

\begin{tabular}{|l|l|l|l|}
\hline Variables & Categories & Frequency & Percent \\
\hline \multirow{3}{*}{ Age } & Below 30 years & 109 & 77.9 \\
\cline { 2 - 4 } & 30 years and above & 31 & 22.1 \\
\hline \multirow{4}{*}{ Education } & PSC & 89 & 63.6 \\
\cline { 2 - 4 } & JSC & 35 & 25.0 \\
\cline { 2 - 4 } & SSC \& HSC & 16 & 11.4 \\
\hline \multirow{3}{*}{ Experience } & Below 5 years & 43 & 30.7 \\
\cline { 2 - 4 } & 5-9 years & 78 & 55.7 \\
\cline { 2 - 4 } & 10 years and above & 19 & 13.6 \\
\hline \multirow{2}{*}{ Wage Distribution } & Below Tk. 10000 & 63 & 45.0 \\
\cline { 2 - 4 } & Tk. 10000 and above & 77 & 55.0 \\
\hline
\end{tabular}

Table 02 demonstrates that all of the workers were males. The age distribution of workers, as shown in table 02 , shows that the majority of workers, $109(77.9 \%)$ of a total of 140, were under the age of 30. The majority of workers who have earned a PSC (Primary School Certificate) or have completed primary education. 78 (55.7 percent) of the 140 respondents had worked for 5 to 9 years and 77 (55 percent) earn more than 10,000 taka per month (per month).

\subsection{Discriminant Validity}

Fornell Larcker's (1981) principle of comparing the AVE value to equivalent correlation values with other variables to evaluate discriminant validity was employed in this study. The square root of AVE had a greater value than the similar association with other factors]. Table 3 shows the discriminant validity of the components.

Table 3: Model validity measures

\begin{tabular}{|l|c|l|l|l|l|l|l|}
\hline & AVE & 1 & 2 & 3 & 4 & 5 & 6 \\
\hline 1. Compensation & 0.633 & 0.796 & & & & & \\
\hline 2. Factory Commitment & 0.791 & 0.344 & 0.889 & & & & \\
\hline 3. Factory People Political Skill & 0.836 & 0.274 & 0.237 & 0.915 & & & \\
\hline 4. Job Satisfaction & 0.630 & 0.189 & 0.212 & 0.539 & 0.794 & & \\
\hline 5. Hand-loom workers Performance & 0.665 & 0.247 & 0.213 & 0.497 & 0.679 & 0.816 & \\
\hline 6. Motivation & 0.693 & 0.322 & 0.343 & 0.327 & 0.297 & 0.357 & 0.833 \\
\hline
\end{tabular}

\subsection{The Measurement model}

To determine if the supplied indicators adequately describe the dimensions, measurement procedures such as Construct Reliability (CR) and Average Variance Extracted (AVE) are used. The extent to which a set of two or more indicators is consistent in representing a construct is known as construct dependability. The greater the construct dependability rating, the more highly connected indicators that focus on the same construct are. The average variance extracted value is evaluated as a supplemental measure of construct dependability to ensure that the high value represents the stated indicators that are actually indicative of the construct. Compensation $(\mathrm{CR}=0.873, \quad \mathrm{AVE}=0.633)$,
Factory Commitment $\quad(\mathrm{CR}=0.938, \quad \mathrm{AVE}=0.791$, Alpha=.808), Factory People Political Skill $(\mathrm{CR}=0.953$, AVE=0.836, Alpha=0.935), Job Satisfaction $(\mathrm{CR}=0.922, \mathrm{AVE}=0.630$, Alpha=0.901), Hand-loom Workers Performance $(\mathrm{CR}=0.888, \quad \mathrm{AVE}=0.665$, Alpha $=0.833)$, and Motivation $(\mathrm{CR}=0.90$, AVE All constructs have a Cronbach Alpha value greater than 0.60 . All factors meet the necessary construct reliability and average variance extracted levels of 0.70 and 0.50 , respectively. The indicator reliability of each study item should be at least 0.40. (Hulland, 1999). Here, all of the study's indicator reliability items are more than 0.40 , indicating that our model's mean indicator is accurately represented.

Table 04: The Construct reliability (CR), Cronbach's alpha, Multicollinearity, Average Variance Extracted (AVE) Value.

\begin{tabular}{|l|c|c|c|c|c|c|c|}
\hline & $\begin{array}{c}\text { Original } \\
\text { Sample }\end{array}$ & $\begin{array}{c}\text { Standard } \\
\text { Deviation }\end{array}$ & $\begin{array}{c}\text { T } \\
\text { Statistics }\end{array}$ & IR & Alpha & CR & AVE \\
\hline COMP1 <- COMP & 0.780 & 0.043 & 18.162 & 0.61 & & & \\
\cline { 1 - 5 } COMP2 <- COMP & 0.788 & 0.041 & 19.148 & 0.62 & \multirow{2}{*}{0.808} & 0.873 & 0.633 \\
\cline { 1 - 5 } COMP3 <- COMP & 0.796 & 0.038 & 21.226 & 0.63 & & \\
\hline COMP4 <- COMP & 0.818 & 0.033 & 24.806 & 0.67 & & \\
\hline
\end{tabular}




\begin{tabular}{|c|c|c|c|c|c|c|c|}
\hline $\mathrm{FC} 1<-\mathrm{FC}$ & 0.874 & 0.025 & 35.427 & 0.76 & \multirow{4}{*}{0.912} & \multirow{4}{*}{0.938} & \multirow{4}{*}{0.791} \\
\hline $\mathrm{FC} 2<-\mathrm{FC}$ & 0.883 & 0.027 & 33.209 & 0.78 & & & \\
\hline FC3 <- FC & 0.906 & 0.021 & 42.223 & 0.82 & & & \\
\hline $\mathrm{FC} 4<-\mathrm{FC}$ & 0.893 & 0.023 & 39.171 & 0.80 & & & \\
\hline FPPS1 <- FPPS & 0.875 & 0.016 & 54.670 & 0.77 & \multirow{4}{*}{0.935} & \multirow{4}{*}{0.953} & \multirow{4}{*}{0.836} \\
\hline FPPS $2<-$ FPPS & 0.936 & 0.009 & 100.131 & 0.88 & & & \\
\hline FPPS3 <- FPPS & 0.921 & 0.014 & 65.293 & 0.85 & & & \\
\hline FPPS4 <- FPPS & 0.925 & 0.013 & 71.934 & 0.86 & & & \\
\hline JS1<- JS & 0.734 & 0.034 & 21.649 & 0.54 & \multirow{7}{*}{0.901} & \multirow{7}{*}{0.922} & \multirow{7}{*}{0.630} \\
\hline JS2 <- JS & 0.830 & 0.028 & 29.431 & 0.69 & & & \\
\hline JS3 <- JS & 0.869 & 0.017 & 50.242 & 0.75 & & & \\
\hline JS4 <- JS & 0.788 & 0.026 & 30.252 & 0.62 & & & \\
\hline JS5 <- JS & 0.835 & 0.021 & 39.241 & 0.70 & & & \\
\hline JS6 <- JS & 0.704 & 0.036 & 19.757 & 0.50 & & & \\
\hline JS7 <- JS & 0.785 & 0.027 & 29.291 & 0.62 & & & \\
\hline LWP1 <- LWP & 0.822 & 0.024 & 33.964 & 0.68 & \multirow{4}{*}{0.833} & \multirow{4}{*}{0.888} & \multirow{4}{*}{0.665} \\
\hline LWP2 <- LWP & 0.807 & 0.027 & 29.418 & 0.65 & & & \\
\hline LWP3 <- LWP & 0.814 & 0.025 & 32.001 & 0.66 & & & \\
\hline LWP4 <- LWP & 0.819 & 0.024 & 34.722 & 0.67 & & & \\
\hline MOT1 <- Motivation & 0.766 & 0.038 & 19.937 & 0.59 & \multirow{4}{*}{0.852} & \multirow{4}{*}{0.900} & \multirow{4}{*}{0.693} \\
\hline MOT2 <- Motivation & 0.892 & 0.015 & 60.637 & 0.80 & & & \\
\hline MOT3 <- Motivation & 0.835 & 0.027 & 31.340 & 0.70 & & & \\
\hline MOT4 <- Motivation & 0.832 & 0.023 & 35.917 & 0.69 & & & \\
\hline
\end{tabular}

Note: Reliability, Alpha=Cronbach's alpha, IR= Indicator Reliability, VIF=Multicollinearity Statistic. [Note: AVE $>0.50$ (Fornell \& Larcker, 1981); Henseler, Ringle, \& Sinkovics, 2009), Composite Reliability>0.70 (Hair et al. 1998), Cronbach‘s alpha $>=0.60$, (Nunnally and Berstein (1994)), Indicator Reliability $>=0.4$ (Hulland, 1999).

\subsection{Exploratory Factor Analysis:}

In social science, EFA is a commonly used and widely implemented statistical technique. This section looked at a total of 140 valid survey replies. By examining job happiness, factory commitment, compensation, motivational factor, factory people political skill, and hand-loom workers performance, the factor analysis technique was used to measure the performance of handloom workers. The rotated factor matrix was used to get the six factors. In the following paragraph, we'll go through those factors in more detail.

Factor-1 (Job Satisfaction): This includes eight variables such as work evaluation, relations with workers, the ability to do other jobs, relations with the factory's master, the factory's financial condition, the ability to learn about production-related work, the ability to change jobs on demand, and relatively attractive wages. To justify the job happiness of hand-loom workers, all criteria are considered.

Factor-2 (Factory Commitment): This component includes receiving a timely and fair compensation or wage, as well as adequate leave on demand and over time. These variables are used to determine whether or not the factory is committed.

Factor-3 (Compensation): Fair salaries, over time (relative to other work or jobs), residential facilities, and other facilities (financial or non-financial) that conceptualize the factor compensation appropriately are all included in the factor compensation.
Factor-4 (Motivational Factor): This variable denotes variables such as a physical problem or work-related health danger, factory owners' behavior, positive behavior from coworkers, and factory owners' ability to face financial crises when necessary.

Factor-5 (Factory People Political Skill): Intrapersonal impact on work, group work for creative work, co-worker knowledge, and transparent work for specified objectives are all factors that clearly characterize factory workers political talent.

Factor-6 (Hand-loom workers Performance): There are five variables that can be used to evaluate the performance of hand-loom workers: rapid production, ability to generate targeted production, best producer (weaver), best performer, and best planner.

Table 05 also shows that at the $1 \%$ level of significance, all of the T-Statistics are greater than 2.33, indicating that the outer model loadings are extremely significant. As a result, our SEM model is acceptable for the studies above findings. In general, path modeling was done using a global fit measure (GOF), which is defined as the geometric mean of average commonality and average R2 (particularly for endogenous variables) (Chin, 2010). (see the formula). For the performance of hand-loom workers in Bangladesh's Shirajganj district, the GOF value was $0.56(\mathrm{R} 2=0.51$, average AVE $=0.61)$. As a result, the GOF value above the biggest cutoff value (0.36), indicating that the suggested model of this study had 
stronger explanatory power than that based on the recommended GOF small $=0.1$, GOF medium $=0.25$,

and GOF large $=0.36$ values (Akter et al., 2011).

$\mathrm{GOF}=\sqrt{ }\left(\mathrm{AVE} \times \mathrm{R}^{\wedge} 2\right)$

Table 05: Cross loading table of the performance of hand-loom workers in Bangladesh.

\begin{tabular}{|c|c|c|c|c|c|c|}
\hline & COMP & $\mathrm{FC}$ & FPPS & JS & LWP & Motivation \\
\hline COMP1 & 0.780 & 0.276 & 0.176 & 0.100 & 0.181 & 0.219 \\
\hline COMP2 & 0.788 & 0.300 & 0.235 & 0.078 & 0.163 & 0.280 \\
\hline COMP3 & 0.796 & 0.201 & 0.212 & 0.178 & 0.200 & 0.250 \\
\hline COMP4 & 0.817 & 0.319 & 0.244 & 0.218 & 0.231 & 0.275 \\
\hline $\mathrm{FC} 1$ & 0.333 & 0.874 & 0.190 & 0.189 & 0.212 & 0.347 \\
\hline FC2 & 0.306 & 0.883 & 0.205 & 0.191 & 0.166 & 0.287 \\
\hline FC3 & 0.274 & 0.906 & 0.231 & 0.178 & 0.184 & 0.290 \\
\hline $\mathrm{FC} 4$ & 0.305 & 0.893 & 0.218 & 0.195 & 0.192 & 0.289 \\
\hline FPPS1 & 0.264 & 0.216 & 0.875 & 0.470 & 0.455 & 0.263 \\
\hline FPPS2 & 0.281 & 0.242 & 0.935 & 0.526 & 0.503 & 0.335 \\
\hline FPPS3 & 0.208 & 0.219 & 0.921 & 0.479 & 0.425 & 0.309 \\
\hline FPPS4 & 0.241 & 0.185 & 0.925 & 0.494 & 0.425 & 0.285 \\
\hline JS1 & 0.189 & 0.166 & 0.389 & 0.734 & 0.564 & 0.289 \\
\hline JS2 & 0.160 & 0.190 & 0.418 & 0.830 & 0.533 & 0.181 \\
\hline JS3 & 0.138 & 0.209 & 0.445 & 0.868 & 0.538 & 0.184 \\
\hline JS4 & 0.153 & 0.174 & 0.375 & 0.788 & 0.504 & 0.217 \\
\hline JS5 & 0.111 & 0.181 & 0.468 & 0.835 & 0.536 & 0.241 \\
\hline JS6 & 0.152 & 0.122 & 0.478 & 0.704 & 0.527 & 0.249 \\
\hline JS7 & 0.142 & 0.133 & 0.417 & 0.785 & 0.558 & 0.282 \\
\hline LWP1 & 0.231 & 0.168 & 0.405 & 0.534 & 0.825 & 0.305 \\
\hline LWP2 & 0.177 & 0.150 & 0.411 & 0.518 & 0.807 & 0.265 \\
\hline LWP3 & 0.228 & 0.178 & 0.405 & 0.528 & 0.817 & 0.318 \\
\hline LWP4 & 0.171 & 0.198 & 0.401 & 0.630 & 0.814 & 0.277 \\
\hline MOT1 & 0.236 & 0.321 & 0.217 & 0.241 & 0.251 & 0.766 \\
\hline MOT2 & 0.260 & 0.284 & 0.314 & 0.266 & 0.328 & 0.892 \\
\hline MOT3 & 0.259 & 0.288 & 0.259 & 0.241 & 0.268 & 0.835 \\
\hline MOT4 & 0.311 & 0.262 & 0.286 & 0.242 & 0.329 & 0.833 \\
\hline
\end{tabular}

\subsection{Common Method Bias Test (HTMT analysis)}

There is no common method bias amongst factors if the association between one factor and another is smaller than 0.85 (Henseler, J., C. M. Ringle, and M. Sarstedt, 2015). As a result of the analysis presented below, it is clear that the value of any other factor's relationship to it is less than 0.85 . As a result, we may conclude that there is no common technique bias in our analysis, as determined by correlation metrics. 


\begin{tabular}{|l|l|l|l|l|l|l|}
\hline & COMP & FC & FPPS & JS & LWP & Motivation \\
\hline COMP & & & & & & \\
\hline FC & 0.399 & & & & & \\
\hline FPPS & 0.311 & 0.256 & & & & \\
\hline JS & 0.210 & 0.234 & 0.586 & & & \\
\hline LWP & 0.297 & 0.242 & 0.561 & 0.781 & & \\
\hline Motivation & 0.385 & 0.391 & 0.361 & 0.338 & 0.419 & \\
\hline
\end{tabular}

\subsection{Structural model assessment}

The structural model is investigated by including path coefficient estimation and variance explained R2 values. We specifically measured all of the hypothesized model's interactions by describing unmediating relationships independently. Bootstrapping (5,000 re-samples) also produces coefficient and t-statistics. The route coefficients between dependent and independent constructs are represented by the structural model. Because these three factors regression coefficient are shown in table-6, this model suggests that three factors such as factory people's political skill, job satisfaction, and motivation have a significantly strong positive effect on hand-loom workers' performance at shirajganj in Bangladesh at a $1 \%$ level of significance. That means that if manufacturing workers' political skills improve by one unit, the performance of hand-loom workers improves by 0.139 units. Hand-loom workers' performance will improve by 0.556 units if job satisfaction is enhanced by one unit. Hand-loom workers' performance will improve by 0.126 units if factory motivation is boosted by one unit. The results and hypothesis testing are presented in Table 6. Because the t-value is greater than 1.96 at the $5 \%$ level of significance, the findings show that the hypotheses $\mathrm{H} 1, \mathrm{H} 4$, and $\mathrm{H} 5$ are supported. $\mathrm{H} 2$ and $\mathrm{H} 3$ were not supported, however, because the t-value was less than 1.96 at the 5\% level of significance. That is, three elements such as job happiness, motivation, and the political skill of factory workers greatly influenced the performance of hand-loom workers in Bangladesh's Shirajganj district. The coefficient of determination $\mathrm{R}$ square for the dependent variable, i.e., the performance of hand-loom workers in Bangladesh's Shirajganj district, is 0.51 , as shown in Table 6. This suggests that the five independent variables of job happiness, motivation, factory people's political skill, remuneration, and factory commitment may explain $51 \%$ of the variation in handloom employees' performance in Bangladesh's Shirajganj district. VIFs (variance inflation factors) range from one to ten. The VIF informs us how much of each coefficient's variance is overstated. In general, a value of 1 indicates that the variables are not correlated, a value of 1-5 indicates that they are moderately correlated, and a value of greater than 5 indicates that they are strongly correlated. VIFs were calculated to investigate the influence of multicollinearity among the variables and found to have a maximum value of 1.517 (Table 6), which is within Hair et al, allowed limit (1998). As a result, there is no concern with multicollinearity in the components. The Standardized Root Mean Square Residual (SRMR) is 0.05, which is less than the proposed satisfactory fit to the data (Table 06). (Hu \& Bentler, 1998). The fit indices indicated that the model was wellfit to the data. When PLS-SEM is predictively relevant, it accurately predicts indicator data points. Hair et al. (2017) found that a Q2 value greater than zero (Q2 value0) for an endogenous latent variable suggests that the PLS path model has predictive importance for this construct. The five independent constructions of factory commitment, compensation, factory personnel political skill, job happiness, and motivation were all linked to the dependent construct, as shown in table-06 (hand-loom workers performance).

Table 06: Regression Weight

\begin{tabular}{|c|c|c|c|c|c|c|c|c|}
\hline Hypothesis & & $\begin{array}{l}\text { Original } \\
\text { Sample } \\
\end{array}$ & $\begin{array}{l}\text { Sample } \\
\text { Mean }\end{array}$ & $\begin{array}{l}\text { Standard } \\
\text { Deviation }\end{array}$ & $\begin{array}{l}\mathrm{T} \\
\text { Statistics }\end{array}$ & $\begin{array}{l}\mathrm{P} \\
\text { Values }\end{array}$ & Comment & VIF \\
\hline $\mathrm{H}_{1}$ & $\begin{array}{ll}\text { JS } & -> \\
\text { LWP } & \\
\end{array}$ & 0.556 & 0.554 & 0.053 & 10.455 & 0.000 & Supported & 1.449 \\
\hline $\mathrm{H}_{2}$ & $\begin{array}{ll}\text { FC } & -> \\
\text { LWP } & \\
\end{array}$ & -0.002 & -0.002 & 0.045 & 0.049 & 0.961 & $\begin{array}{l}\text { Not } \\
\text { Supported }\end{array}$ & 1.233 \\
\hline $\mathrm{H}_{3}$ & $\begin{array}{l}\text { COMP } \quad-> \\
\text { LWP }\end{array}$ & 0.064 & 0.068 & 0.043 & 1.463 & 0.144 & $\begin{array}{l}\text { Not } \\
\text { Supported }\end{array}$ & 1.229 \\
\hline $\mathrm{H}_{4}$ & $\begin{array}{l}\text { Motivation } \\
\text {-> LWP }\end{array}$ & 0.126 & 0.127 & 0.042 & 3.006 & 0.003 & Supported & 1.286 \\
\hline $\mathrm{H}_{5}$ & $\begin{array}{ll}\text { FPPS } & -> \\
\text { LWP } & \end{array}$ & 0.139 & 0.138 & 0.053 & 2.628 & 0.009 & Supported & 1.517 \\
\hline \multicolumn{3}{|c|}{$\mathrm{R}$-square value } & \multicolumn{6}{|c|}{0.51} \\
\hline \multirow{2}{*}{ Model Fit } & \multicolumn{2}{|l|}{ SRMR } & \multicolumn{6}{|c|}{0.05} \\
\hline & \multicolumn{2}{|l|}{$\mathrm{Q}^{2}$ value } & \multicolumn{6}{|c|}{0.375} \\
\hline
\end{tabular}

Note: Q2 Value $>0$ (Stone1974, Geisser's, 1974), Collinearity Statistic (VIF): The rule of thumb for the VIF is as follows: 
VIF $<3$; no problem.]

\subsection{Conclusion}

Social effectiveness is critical for any effective interpersonal interaction and, more significantly, any work-related situation. Individuals' affective and behavioral reactions in organizational settings are significantly influenced by social effectiveness constructs (Smith, Plowman, Duchon, \& Quinn, 2009). Interpersonal influence refers to the ability to have a strong influence on those with whom one works, and people with a high level of interpersonal influence have a strong ability to persuade others and may adjust this ability to different types of influence targets (Blickle , Oerder \& Summers, 2010). Effective political skill allows a worker to influence subordinates in ways that benefit the organization. It is also an interpersonal style that blends social savvy with the ability to connect with others and inspire confidence, trust, and gaminess. (Smith, Plowman, Duchon, \& Quinn,2009). Intrapersonal impact on work, group work for creative work, co-worker knowledge, and transparent work for specified objectives are all factors that clearly characterize factory workers political talent. In the case of the handloom industry, various things encourage the handloom owner to engage in the sector. Some are motivated by a great desire to provide for their families, while others are motivated by the goal to make them self-sufficient (Datta, 2020). This element is influenced by a number of key variables, including physical problems or work-related health hazards, factory owner behavior, positive coworker behavior, and the ability of factory owners to face financial crises when necessary. According to Vroom (1964) Employees' emotional orientation towards the role they play at work is referred to as job satisfaction (Abdul $\&$ Maulabakhsh, 2014). From eight selected variables, there found seven significant variable respectively evaluation of work, relation with workers, opportunity of doing other jobs, relation with master of the factory, financial condition of factory, opportunity of learning regarding the production related work and opportunity of work change on demand. All the variables are evaluated to justify the job satisfaction of hand-loom workers. We can conclude from the preceding discussion that man enjoys working in his factory for this purpose, i.e. Satisfied has a spiritual relationship with those who work in the factory, and the factor that is involved is whether the motivation is financial or verbal, because people can promise what they cannot pay for. So, just as the factory workers will live if the factory's bosses consider this side, the factory will go forward day by day based on its performance in order to do better in the future. Another significant issue is that the factory owner should take great care to ensure that the employees are happy with their jobs, for example, by announcing various incentives that will encourage the workers to work longer hours in their own factory. The sample size was quite small, and only a few criteria were investigated, which is one of the study's shortcomings. If more elements are considered, the study will produce useful results that may be used to boost the factory's production.

\section{References}

[1] Benrazavi, S. R., \& Silong, A. D. (2013). Employees' job satisfaction and its influence on willingness to work in teams. Journal of Management Policy and Practice, 14(1), 127-140.

[2] PRELIMINARY REPORT (HANDLOOM CENSUS 2018). Bangladesh Bureau of Statistics (BBS), Statistics and Informatics Division. Project Director, Handloom Census 2017, Project

[3] Kim, H. S., \& Jang, S. S. (2020). The effect of increasing employee compensation on firm performance: Evidence from the restaurant industry. International Journal of Hospitality Management, 88, 102513.

[4] Apu, A. A. (2007). Reviving Bangladesh handloom industry through adoption and diffusion process.

[5] Cohen, A. (2007). Commitment before and after: An evaluation and reconceptualization of organizational commitment. Human resource management review, 17(3), 336-354.

[6] Diamantidis, A. D., \& Chatzoglou, P. (2019). Factors affecting employee performance: an empirical approach. International Journal of Productivity and Performance Management.

[7] Smith, A. D., Plowman, D. A., Duchon, D., \& Quinn, A. M. (2009). A qualitative study of high-reputation plant managers: Political skill and successful outcomes. Journal of Operations Management, 27(6), 428-443.

[8] B. Dutta (2020) "Motivating Factors And Problems Of Handloom Industry, A Study In Dhemaji District of Assam," INTERNATIONAL JOURNAL OF SCIENTIFIC \& TECHNOLOGY RESEARCH, vol. 09, no. 03, pp. 7133-7137.

[9] Banister, C. M., \& Meriac, J. P. (2015). Political skill and work attitudes: A comparison of multiple social effectiveness constructs. The Journal of psychology, 149(8), 775-795.

[10] Roy, C. (2017). The silk handloom industry in Nadia district of West Bengal: a study on its history, performance \& current problems. New Man International Journal of Multidisciplinary Studies (ISSN: 2348-1390), 4(7), 50-66.

[11] Srivastava, D. K. (2017). Power driven looms: The Indian decentralised textile sector. International Journal of Engineering, Science and Mathematics, 6(7), 97-107.

[12] Aboagye, E., Björklund, C., Gustafsson, K., Hagberg, J., Aronsson, G., Marklund, S., ... \& Bergström, G. (2019). Exhaustion and impaired work performance in the workplace: Associations with presenteeism and absenteeism. Journal of occupational and environmental medicine, 61(11), e438-e444.

[13] Chin, W. W. (2010). How to write up and report PLS analyses. In Handbook of partial least squares (pp. 655-690) Springer, Berlin, Heidelberg.

[14] Fornell, C., \& Larcker, D. F. (1981). Structural equation models with unobservable variables and measurement error: Algebra and statistics. Journal of marketing research, 382388.

[15] Hair, J. F., Black, W. C., Babin, B. J., Anderson, R. E., \& Tatham, R. L. (1998). Multivariate data analysis, 5 (3), $207-$ 219. Upper Saddle River, NJ: Prentice hall.

[16] Hair, J. F., Ringle, C. M., \& Sarstedt, M. (2011). PLSSEM: Indeed a Silver Bullet Journal of Marketing Theory and Practice, 19 (2) pages 139-152, doi: 10.2753. MTP10696679190202.

[17] Hair, J. F., Ringle, C. M., \& Sarstedt, M. (2011). PLSSEM: Indeed a Silver Bullet Journal of Marketing Theory and 
Practice, 19 (2) pages 139-152, doi: 10.2753. MTP10696679190202 .

[18] Hair, J. F., Sarstedt, M., Ringle, C. M., \& Mena, J. A. (2012). An assessment of the use of partial least squares structural equation modeling in marketing research. Journal of the academy of marketing science, 40(3), 414-433.

[19] Henseler, J., Ringle, C. M., \& Sinkovics, R. R. (2009). The use of partial least squares path modeling in international marketing. In New challenges to international marketing (pp. 277-319). Emerald Group Publishing Limited.

[20] Henseler, J., Ringle, C. M., \& Sarstedt, M. (2012). Using partial least squares path modeling in advertising research: basic concepts and recent issues. In Handbook of research on international advertising. Edward Elgar Publishing.

[21] Hoyle, R. H. (1995). Structural equation modeling: Concepts, issues, and applications. Sage.

[22] Hulland, J. (1999). Use of partial least squares (PLS) in strategic management research: A review of four recent studies. Strategic management journal, 20(2), 195-204.

[23] Nunnally, J. C., \& Bernstein, I. H. (1994). The assessment of reliability. Psychometric theory, 3(1), 248-292.

[24] O'connor, B. P. (2000). SPSS and SAS programs for determining the number of components using parallel analysis and Velicer's MAP test. Behavior research methods, instruments, \& computers, 32(3), 396-402.

[25] Stone, M. (1974). Cross-validatory choice and assessment of statistical predictions. Journal of the royal statistical society: Series B (Methodological), 36(2), 111-133.

[26] Geisser, S. (1974). A Predictive Approach to the Random Effects Model, Biometrika, 61(1): 101-107.

[27] Morgeson, F. P., Campion, M. A., \& Maertz, C. P. (2001). Understanding pay satisfaction: The limits of a compensation system implementation. Journal of Business and Psychology, 16(1), 133-149.

[28] Sharmin, F., \& Hossain, S. T. (2020). Revitalization of handloom communities for preserving the craft heritage of Bangladesh. Urban and Regional Planning, 5(1), 1-10..

[29] Randhawa, G. (2007). Work performance and its correlates: An empirical study. Vision, 11(1), 47-55.

[30] Einolander, J. (2015). Evaluating organizational commitment in support of organizational leadership. Procedia Manufacturing, 3, 668-673

[31] Bentley, J. R., Robinson, J. L., \& Zanhour, M. (2021). Managerial political skill and achieved supply chain integration: the mediating effects of supply chain orientation and organizational politics. Supply Chain Management: An International Journal.

[32] K. Anumala and N. Samal, "Impact of Supply Chain Management Practices on Product Quality in Indian Handloom Industry with reference to Master Weavers," International Journal for Advanced Research, vol. 5, no. 6, pp. 2005-2014, 2017.

[33] Raihan, M. A. (2010). Handloom: an option to fight rural poverty in Bangladesh. Asia-Pacific journal of rural development, 20(1), 113-130.

[34] Islam, M. K., \& Hossain, M. E. (2012). An analysis of Present Scenario of Handloom Weaving Industry in Bangladesh. Rabindra Journal, 3(1), 13-28.

[35] Islam, M. K., \& Hossain, M. E. (2018). Determinants of profitability of handloom weaving units operating in Kumarkhali Upazila of Kushtia District in Bangladesh. International Journal of Research in Business Studies and Management, 5(5), 1-7.

[36] Islam, M. K., Hossain, M. E., \& Ghosh, B. C. (2013). Costbenefit analysis of handloom weaving industry in kumarkhali upazila of Kushtia District, Bangladesh. Development Compilation, 9(01), 64-72.

[37] Rahman, M. M. (2013). Prospects of Handloom Industries in Pabna, Bangladesh. Global Journal of Management And Business Research.

[38] Liton, M. R. I., Islam, T., \& Saha, S. (2016). Present scenario and future challenges in handloom industry in Bangladesh. Social Sciences, 5(5), 70-76.

[39] Liton, M. R. I. (2020). Profit disparities in handloom industry: A unit level analysis. Thematics Journal of Sociology, 4(2).

[40] Parvin, M. T., \& Haque, S. (2017). An Analysis of Socioeconomic Indicators of Rural Non-Agricultural Households in Bangladesh: A Case of Handloom Weaving. Journal of Economics and Sustainable Development, 8 (12), 1-12.

[41] Parvin, M. T., Fatema, K., \& Haque, S. (2020). Factors Determining the Credit Accessibility by the Small-Scale Entrepreneurs: A Case of Handloom Weaving in Bangladesh. International Journal of Business and Management, 15(8).

[42] Patnaik, P., \& Suar, D. (2019). Analyses of publications on compensation management from 2004 to 2017. Compensation \& Benefits Review, 51(2), 55-76.

[43] R. Abdul and R. Maulabakhsh, "Impact of Working Environment on Job Satisfaction," in Procedia Economics and Finance, 2014

[44] R. Barontini and S. Bozzi, "Board compensation and ownership structure: empirical evidence for Italian listed companies," Springer , pp. 59-89, 2009.

[45] Vosloban, R. I. (2012). The Influence of the Employee's Performance on the company's growth-a managerial perspective. Procedia economics and finance, 3, 660-665.

[46] Banarjee, S., Muzib, M. M., \& Sharmin, S. (2014). Status of handloom workers and causes of their migration: A study in handloom industry of Tangail district, Bangladesh. Research on humanities and social sciences, 4(22), 157-162.

[47] S Tan, S. K., \& Rajah, S. (2019). Evoking work motivation in Industry 4.0. SAGE Open, 9(4), 2158244019885132.

[48] Lee, K. W., Lev, B., \& Yeo, G. H. H. (2008). Executive pay dispersion, corporate governance, and firm performance. Review of Quantitative Finance and Accounting, 30(3), 315-338.

[49] Blickle, G., Oerder, K., \& Summers, J. K. (2010). The impact of political skill on career success of employees' representatives. Journal of Vocational Behavior, 77(3), 383 390.

Abid Aziz, School of Business, Uttara University

Md. Monowar Uddin Talukdar, Department of Business Administration, Khwaja Yunus Ali University.

Mitaly Rani Sarkar, Officer, Rupali Bank Ltd.

Mohitul Ameen Ahmed Mustafi, Department of Business Administration, Khwaja Yunus Ali University, Bangladesh. 